\title{
Die zivilrechtliche Haftung für Mitspielerverletzungen bei Sport und Spiel
}

\author{
Bespreking van het proefschrift van Philipp Dördelmann
}

\author{
Dr.P.C.J. De Tavernier*
}

\section{Inleiding}

'The timorous may stay at home.' ${ }^{1}$ Oftewel: wie zich niet wil blootstellen aan de risico's die sport en spel met zich meebrengen, die blijft maar beter achter de geraniums zitten. De wijsheid van de Amerikaanse rechter Benjamin Cardozo houdt, juridisch gesproken, in dat voor wie deelneemt aan een recreatieve activiteit de regel geldt dat er geen sprake is van een 'duty of care' met betrekking tot de inherente risico's die de beoefende activiteit met zich meebrengt. ${ }^{2}$ Hoever reiken die inherente risico's dan wel? Moeten deelnemers aan sport en spel van hun medespelers ook onzorgvuldige gedragingen op de koop toe nemen? ${ }^{3}$ Over deze vraag is al veel inkt gevloeid. Denk maar aan de talrijke bijdragen die in de afgelopen jaren zijn verschenen over de theorie van de risicoaanvaarding bij sport en spel. ${ }^{4}$ Een systematische analyse van de problematiek van de civiele aansprakelijkheid van medespelers ontbrak tot op heden echter. Het fraaie Duitse proefschrift van Dördelmann ${ }^{5}$ vult deze lacune op.

Op het eerste gezicht lijkt het thema waar Dördelmann zijn boek aan heeft gewijd, niet erg spannend. Zijn de meeste rechtsvragen met betrekking tot de aansprakelijkheid die deel-

Dr. P.C.J. De Tavernier is universitair docent aan de Universiteit Leiden, meer bepaald aan de Afdeling Burgerlijk Recht (Instituut voor Privaatrecht). Hij is als bijzonder academisch personeelslid ook verbonden aan de Universiteit Antwerpen.

1. Murphy v Steeplechase Amusement Co., 166 N.E. 173, 174 (N.Y. 1929).

2. Zie daarover uitvoerig E.A. Feldman \& A. Stein, Assuming the Risk: Tort Law, Policy, and Politics on the Slippery Slopes, Depaul Law Review 2010, p. 259-304.

3. Zie daarover J.H. Chalat, Avalanche Liability Law \& Ski Law in the United States. A Practical Guideline to Ski Accident Litigation, te raadplegen via www.chalatlaw.com.

4. Zie bijv. de erg fraaie analyse over deze theorie, naar Nederlands recht, van B.M. Paijmans, Sport en spel. In de verlenging?, L\&S 2015, afl. 4, p. 6 e.v.

5. Philipp Dördelmann, Die zivilrechtliche Haftung für Mitspielerverletzungen bei Sport und Spiel, in: Beiträge zum Sportrecht, Band 55, Berlijn: Duncker \& Humblot 2018. De auteur heeft zijn proefschrift in 2018 met succes verdedigd aan de Ruhr Universität Bochum (Duitsland). nemers aan sport en spel onderling kunnen oplopen, immers niet uitgekristalliseerd in rechtsleer en jurisprudentie? Denk in dit verband bijvoorbeeld aan de impact van sport- en spelregels bij de toetsing van de zorgvuldigheidsnorm of de vraag of de risicoaanvaarding nog als een zelfstandig leerstuk kan worden aangewend.

Mijn voorzichtige twijfel over het vernieuwende karakter van de studie van Dördelmann neemt niet weg dat het boek als een niet te onderschatten nieuwe loot aan de stam van de juridische literatuur over de problematiek van de aansprakelijkheid in sport en spel mag worden aangemerkt, en wel om de volgende redenen. In de eerste plaats heeft de auteur een indrukwekkende inspanning geleverd om de problematiek op een allesomvattende en systematische wijze te presenteren. In een eerdere bespreking van het boek van Dördelmann schrijft Rafael Brägger terecht:

'Das Werk überzeugt durch juristischen Tief(st)gang sowie stringente, widerspruchsfreie Argumentation. Die Thematik wird umfassend und auf hohem wissenschaftlichem Niveau, gleichwohl nutzbringend für die Praxis abgehandelt. ${ }^{6}$

Met andere woorden: een diepgaande studie, overtuigend beargumenteerd, volledig en van hoog wetenschappelijk niveau, en tegelijk nuttig voor de rechtspraktijk. In de tweede plaats doet Dördelmann een verdienstelijke poging om met behulp van een helder referentiekader, ${ }^{7}$ namelijk de eigen aard van de beoefende sport- of spelactiviteit ('Typizität') enerzijds en de wederzijdse kans van deelnemers om bij sport en spel schade te lijden ('Reziprozität') anderzijds, een antwoord te geven op de vraag waarom er in geval van aansprakelijkheid voor schade van deelnemers die tijdens sport en spel met elkaar wedijveren, kan worden afgeweken van de zorgvuldig-

6. Zie de bespreking van het boek van Philipp Dördelmann door R. Brägger in Causa Sport 2019, afl. 1, p. 1-2.

7. Zie Dördelmann 2018, p. 39 e.v. 


\section{Maandblad}

heidsnorm die in het aansprakelijkheidsrecht van toepassing zou zijn bij schadegevallen die zich buiten sport- en spelsituaties voordoen. Ten slotte daagt de auteur de lezer voortdurend uit om met hem in discussie te treden over de vele theorieën ${ }^{8}$ die voor de oplossing van de onderzochte problematiek in rechtsleer en rechtspraak zijn aangereikt, hierbij inbegrepen de criteria die voor de toetsing van de zorgplicht die deelnemers onderling in acht moeten nemen, ${ }^{9}$ als relevant kunnen worden bestempeld. Al deze leerstukken en criteria worden door Dördelmann op een diepgaande en beargumenteerde wijze op hun merites beoordeeld.

Dördelmann houdt de rechtspracticus een heldere spiegel voor met betrekking tot velerlei relevante rechtsvragen die bij een onderzoek naar de reikwijdte van de civiele aansprakelijkheid van deelnemers onderling bij sport- en spelsituaties een antwoord moeten krijgen. Om die reden heb ik de recensie opgebouwd als een vergelijking van zeven van de door Dördelmann verdedigde stellingen met de principes die in het vigerende recht van onder meer Nederland en België en in het AngloAmerikaanse recht daaromtrent zijn ontwikkeld. ${ }^{10}$ In deze recensie betrek ik daarbij twee van elkaar te onderscheiden sporten: de voetbalsport enerzijds, een contactsport bij uitstek, en de skisport anderzijds, een (in beginsel) niet-contactsport.

\section{Inhoudelijke analyse}

\subsection{Stelling 1: over de 'Typizität des Sports' en de 'Reziprozität der Verletzungsgefahr'}

'Die Typizität des Sports und die Reziprozität der Verletzungsgefahr stellen zwei wesentliche gefahrenhöhende Merkmale bei der Sportübung dar, bei deren kumulativen Vorliegen eine Haftungsbeschränkung zugunsten des schädigenden Sportlers gerechtfertigt erscheint. ${ }^{\text {'1 }}$

Met andere woorden: de begrenzing van de aansprakelijkheid van deelnemers aan sport- en spelsituaties onderling berust op een dubbele grondslag: de eigen aard van de activiteit (de 'Typizität', oftewel de 'Eigenart') van de sport of het spel enerzijds en het wederzijdse karakter van het risico om letselschade toe te brengen ('Reziprozität', oftewel 'Wechselseitigkeit der Verletzungsgefahr') anderzijds. Deze stelling is voor de Nederlandse jurist niet bijzonder verrassend. De rechtspraak erkent

8. Zo behandelt Dördelmann onder meer de volgende theorieën: 'Sport als rechtsfreier Raum', 'rechtfertigende Einwilligung' en 'Verschuldensmodifikation'.

9. Zie bijv. over 'Abgrenzungskriterien zwischen privilegierten und missbilligten Mitspielerverletzungen’ Dördelmann 2018, p. 309 e.v.

10. Dördelmann bespreekt in zijn boek alleen het Duitse recht. Het betreft dus geen rechtsvergelijkende studie. De buitencontractuele aansprakelijkheid, op grond van $₫ 823$, eerste alinea BGB, toegepast op schade tussen deelnemers aan sport- en spelsituaties onderling, vormt het centrale thema van Dördelmanns studie. Uit mijn onderzoek moge blijken dat de stellingen die Dördelmann naar Duits recht verwoordt, nauw aansluiten bij de oplossingen die het Nederlands recht over de behandelde problematiek aanreikt.

11. Dördelmann 2018, p. 350. immers de inherente risico's en de eigen normen van sport en spel waar het deelnemers aan sport- en spelactiviteiten onderling betreft. ${ }^{12}$ De deelname op eigen verantwoordelijkheid aan sport en spel kleurt binnen die verhouding de maatschappelijke zorgvuldigheidsnorm, zoals vervat in art. 6:162 lid 2 BW, in. De drempel voor onrechtmatigheid ligt daarom tussen sporters hoger dan het geval zou zijn in een dagelijkse situatie. Deelnemers aan een sport of spel hebben in redelijkheid tot op zekere hoogte gevaarlijke, slecht gecoördineerde, verkeerd getimede of onvoldoende doordachte gedragingen waartoe die activiteit aanleiding geeft, van elkaar te verwachten. ${ }^{13}$ De aan te leggen gedragsnorm is daarbij sterk gebonden aan de context waarbinnen de gedraging zich situeert, namelijk de sport- of spelsituatie. Ook naar Belgisch recht wordt rekening gehouden met de context van de sport- of spelsituatie. Zo is een deelnemer aan sport of spel wel onderworpen aan de regel van de foutaansprakelijkheid, maar zal de feitenrechter rekening houden met de concrete omstandigheden van het geval, zoals de regels eigen aan een bepaalde sport- of spelactiviteit. ${ }^{14}$ Over de impact van die regels gaat de volgende stelling.

\subsection{Stelling 2: over de impact van de sport-en spelregels}

'Die Sportregelwerke - auch die FIS-Regeln für den alpinen Wintersport - sind weder Rechtsnormen noch Gewohnheitsrecht. Sie sind vielmehr als außergesetzliche Verhaltensvorschriften zu qualifizieren, die aufgrund dieses Status zur Konkretisierung der Verhaltenspflichten im Binnenverhältnis der Sportler herangezogen werden können.' ${ }^{15}$

In de literatuur en de jurisprudentie over aansprakelijkheid van deelnemers aan sport- en spelactiviteiten wordt ruime aandacht besteed aan de impact van de van toepassing zijnde sport- en spelregels. ${ }^{16}$ Daarbij worden meestal de volgende principes vooropgesteld. $\mathrm{Bij}$ de vestiging van de aansprakelijkheid houdt de rechter rekening met de sport- en spelregels, maar op zichzelf is noch de naleving, noch de miskenning van die regels bepalend. Doorslaggevend is of het gedrag van de deelnemer al dan niet strookt met het gedrag van een normaal voorzichtige en redelijk handelende persoon, geplaatst in (identiek) dezelfde feitelijke omstandigheden. Ook het overtreden van een spelregel die is geschreven ter bescherming van de veiligheid van de speler, levert niet zonder

12. Zie hierover A.F. van Gent, Van strenge aansprakelijkheid van de professionele sportorganisator naar eigen verantwoordelijkheid van de amateursporter (masterscriptie Leiden), 2018, p. 13. De scriptie van Van Gent, voor wie ik als scriptiebegeleider ben opgetreden, werd in 2019 bekroond met de Mr. N.J.P. Giltay Veth-scriptieprijs.

13. Zie HR 28 juni 1991, ECLI:NL:HR:1991:ZC0300, NJ 1992/622 m.nt. C.J.H. Brunner (Natrappen).

14. Zie daarover H. Vandenberghe, Onrechtmatige daad (2000-2008). Deel II. Foutvereiste. Algemene kenmerken, TvPr. 2010, p. 1995 e.v., nrs. 74 e.v.

15. Dördelmann 2018, p. 351.

16. Zie naar Belgisch recht bijv. Vandenberghe 2010, p. 1993 e.v. Zie naar Nederlands recht bijv. C. van Dam, Aansprakelijkheidsrecht, Den Haag: Boom Juridische uitgevers 2000, p. 431-433, nr. 1518. 


\section{Maandblad \\ Vermogensrecht}

Tabel 1

\begin{tabular}{lll}
\hline & FIS-regels geschonden? & Onrechtmatig gehandeld? \\
\hline ECLI:NL:GHSHE:1998:AK3920 & Ja & Ja \\
ECLI:NL:RBGRO:1998:AK3941 & $\mathrm{Ja}$ & $\mathrm{Ja}$ \\
ECLI:NL:RBAMS:2000:AJ6775 & $\mathrm{Ja}$ & $\mathrm{Ja}$ \\
ECLI:NL:GHLEE:2012:BW9768 (Unigarant) & $\begin{array}{l}\text { Een schending van de FIS-regels kan } \\
\text { niet worden bewezen }\end{array}$ & Nee \\
ECLI:NL:RBROT:2015:5696 & $\begin{array}{l}\text { Een schending van de FIS-regels kan } \\
\text { niet worden bewezen }\end{array}$ & Nee \\
ECLI:NL:RBNHO:2018:1184 & $\mathrm{Ja}$ & $\mathrm{Ja}$ \\
\hline
\end{tabular}

meer onrechtmatigheid op. ${ }^{17}$ Deze algemene observaties geven geen duidelijk beeld van de precieze impact van de sport- en spelregels op het oordeel of een deelnemer voor door hem veroorzaakte schade aansprakelijk kan worden gesteld. Daarvoor is nader jurisprudentieonderzoek vereist. Afgelopen jaar heeft Merel van Bunge, in het raam van haar masterscriptietraject, een interessante studie verricht over het gewicht dat aan sportregels wordt toegekend in twee duidelijk van elkaar te onderscheiden sportdisciplines, namelijk de skisport (een niet-contactsport) en de voetbalsport (in beginsel een contactsport). ${ }^{18}$

Voor de invulling van de zorgvuldigheidsnorm in de skisport wordt een beroep gedaan op de zogenaamde FIS-regels. ${ }^{19}$ Deze regels staan voor de gedragsregels van de Fédération Internationale du Ski. De FIS-regels beogen de veiligheid op de piste in goede banen te leiden. Zo houdt een van die regels, FISregel 3, in dat de skiër die van achter komt zijn route op de piste zo moet kiezen dat hij geen gevaar creëert voor de skiër voor hem. Uit het door Van Bunge gevoerde onderzoek blijkt nu dat als er sprake is van een schending van de FIS-regels en dit bewezen kan worden, vrijwel altijd tot onrechtmatigheid wordt besloten.

Van Bunge heeft haar bevindingen omtrent de impact van de FIS-regels op het onrechtmatigheidsoordeel op een overzichtelijke wijze gepresenteerd (zie tabel 1). ${ }^{20}$

Slechts in twee gevallen waarin een schending van de FISregels niet bewezen kon worden, werd onrechtmatigheid niet aangenomen. Daarmee lijken de FIS-regels een (zeer) belang- rijke en bepalende rol te spelen bij de afweging of er al dan niet onrechtmatig is gehandeld. ${ }^{21}$ Zo oordeelde de rechtbank Amsterdam:

'Alhoewel de FIS-regels slechts het karakter van een aanbeveling hebben, staat vast dat zij ruime internationale erkenning en bescherming genieten. Zij spelen dan ook een belangrijke rol bij de beantwoording van de vraag of er onrechtmatig is gehandeld. ${ }^{22}$

Van Dam sluit zich bij deze opvatting aan:

'In een sport als skiën geldt dat het niet volgen van de FISregels in beginsel onrechtmatig is. Dat is het geval, omdat de FIS-regels concreet zijn geformuleerd en de skisport uitstekend kan worden beoefend met inachtneming van deze regels. Wel kan de toerekenbaarheid van de onrechtmatige gedraging wegens verontschuldigbare onervarenheid ontbreken, bijvoorbeeld wanneer iemand in een beginnersklas voor skiërs tegen een medeleerling valt en zo een dominoeffect creëert. ${ }^{23}$

Ook bij de voetbalsport blijkt de grote impact van de sportregels op het onrechtmatigheidsoordeel. Uit het rechtspraakonderzoek dat Van Bunge heeft uitgevoerd, blijkt namelijk dat, relatief gezien, in meer gevallen wordt geoordeeld dat er sprake is van onrechtmatigheid als bewezen is dat de spelregels geschonden zijn. Slechts in een minderheid van rechterlijke uitspraken komt men bij een overtreding van de spelregels vervolgens niet tot onrechtmatigheid. ${ }^{24}$

17. Zie daarover bijv. L. Cornelis \& I. Claeys, Sport en aansprakelijkheid. Een stand van zaken, TBBR 2003, p. 584 e.v.

18. M. van Bunge, Rode kaart onrechtmatige daad? In hoeverre weegt een overtreding van de spelregels mee als gezichtspunt bij het vaststellen van een onrechtmatige daad bij een sport- of spelsituatie? (masterscriptie Leiden), 2019 (niet gepubliceerd, maar op aanvraag verkrijgbaar).

19. Zie over de FIS-regels bijv. A. Kaltenegger \& K. Schöllnast, Pistenregeln - ein Überblick. Gesamtüberblick zu den Verhaltensregeln auf Schipisten in Österreich, Bedeutung der FIS-Regeln in Europa, Zeitschrift für Verkehrsrecht 2007, p. 47-53.

20. Van Bunge 2019, p. 13-14.

21. Van Bunge 2019, p. 14; zie ook Van Dam 2000, p. 432, nr. 1518.

22. Rb. Amsterdam 15 november 2000, ECLI:NL:RBAMS:2000:AJ6775, r.o. 4 .

23. Van Dam 2000, p. 432.

24. Van Bunge 2019, p. 17. 


\begin{tabular}{lll}
\hline & $\begin{array}{l}\text { Bewezen dat de spelregels geschon- } \\
\text { den zijn? }\end{array}$ & Onrechtmatig gehandeld? \\
\hline ECLI:NL:RBZWO:1986:AJ5424 & $\mathrm{Ja}$ & $\mathrm{Ja}$ \\
ECLI:NL:HR:1991:ZC0300 & $\mathrm{Ja}$ & $\mathrm{Ja}$ \\
ECLI:NL:KTGZWO:1999:AJ0061 & Ja, gele kaart & Nee \\
ECLI:NL:GHARN:2007:BB3745 & $\begin{array}{l}\text { Ja, rode kaart en 4 wedstrijden } \\
\text { geschorst door tuchtcommissie }\end{array}$ & $\mathrm{Nee}$ \\
ECLI:NL:RBSGR:2008:BC3860 & Ja, rode kaart en 4 weken geschorst & $\mathrm{Ja}$ \\
& door tuchtcommissie & $\mathrm{Ja}$ \\
ECLI:NL:RBARN:2008:BD1779 & $\mathrm{Ja}$ & $\mathrm{Ja}$ \\
ECLI:NL:RBHAA:2009:7675 & $\mathrm{Ja}$ & $\mathrm{Ja}$ \\
ECLI:NL:GHAMS:2011:BX7845 & $\mathrm{Ja}$ & $\mathrm{Nee}$ \\
ECLI:NL:RBNNE:2016:1502 & Nee & Nee \\
ECLI:NL:RBDHA:2017:4845 & $\mathrm{Ja}$ &
\end{tabular}

Ook met betrekking tot de voetbalsport geeft Van Bunge een mooi overzicht van de bevindingen van haar jurisprudentieonderzoek (zie tabel 2). ${ }^{25}$

\subsection{Stelling 3: over de leer van de risicoaanvaarding}

'Der Rückgriff auf ein Handeln auf eigene Gefahr kann sich nicht als zielführend erweisen. Aus der Ferne betrachtet kann die Sportausübung zwar durchaus als Unterfall des Handelns auf eigene Gefahr klassifiziert werden, allerdings resultieren daraus keine rechtlichen Folgen im Sinne dieses Rechtsinstituts. ${ }^{26}$

In zijn boek European Tort Law merkt Cees van Dam over de figuur van de risicoaanvaarding ('assumption of risk') fijntjes op:

'Systematically, the concept is hybrid, since it is related to contributory negligence, defences and grounds of justification, and negligence. In practice, the concept has chameleon-like features because its application very much depends on the circumstances of the case. ${ }^{.27}$

Naar Nederlands recht bestaat er, gelet op vaste rechtspraak van de Hoge Raad, ${ }^{28}$ geen twijfel meer over dat risicoaanvaarding als zelfstandig verweermiddel heeft afgedaan. De aan-

25. Van Bunge 2019, p. 17-18.

26. Dördelmann 2018, p. 148-149.

27. C. van Dam, European Tort Law, Oxford: Oxford University Press 2013, p. 256, nr. 809-3.

28. Zie HR 28 juni 1991, ECLI:NL:HR:1991:ZC0300, NJ 1992/622 m.nt. C.J.H. Brunner (Natrappen). sprakelijkheid in sport- en spelsituaties wordt naar Nederlands recht uitsluitend nog beoordeeld aan de hand van de zorgvuldigheidsnorm ('duty of care') en eigen schuld ('comparative negligence') van de benadeelde. ${ }^{29}$ Dit laatste zal bijvoorbeeld het geval zijn als de benadeelde, tijdens het beoefenen van de voetbalsport, het natrappen zou hebben uitgelokt, bijvoorbeeld door treiteren of door bovenmatig hard spel ten aanzien van de benadeelde of diens ploeggenoten. Het feit, evenwel, dat bekend is dat onsportief gedrag vaker voorkomt, is geen grond om het enkel deelnemen aan die sport als (gedeeltelijke) eigen schuld aan de benadeelde toe te rekenen. Bekendheid met het feit dat er spelers zijn die dergelijke schoppen uitdelen en daarmee onnodig blessures veroorzaken, sluit immers niet uit dat een voetbalspeler ervan mag uitgaan dat de andere spelers op het veld zich behoorlijk zullen gedragen en niet onnodig blessures zullen veroorzaken.

Ik kan mij volkomen vinden in deze zienswijze. Lange tijd ging men ervan uit dat het slachtoffer geen recht op schadevergoeding had, omdat hij de gevolgen van zijn deelname aan een risicovolle activiteit had aanvaard. Terecht hebben auteurs ervoor geijverd om de theorie van de risicoaanvaarding opzij te schuiven, omdat deze leer niets toevoegt aan het bestaande recht. Als er redenen zijn om het slachtoffer niet (volledig) te compenseren, dan biedt het bestaande recht hiervoor twee opties. Ofwel blijft het slachtoffer met zijn schade zitten ('damage lies where it falls') omdat de aangesprokene ten aanzien van hem geen zorgplicht heeft ('no duty of care') of tegenover hem geen fout heeft begaan, waardoor aansprakelijkheid ontbreekt, ofwel omdat er weliswaar sprake is

29. Paijmans 2015, p. 8 . 


\section{Maandblad \\ Vermogensrecht}

van een aansprakelijke derde, maar er omstandigheden zijn aan te wijzen op grond waarvan het slachtoffer een deel of het geheel van zijn schade zelf moet dragen.

Toch belet deze wijsheid de meeste rechters niet om op regelmatige wijze naar de leer van de risicoaanvaarding te verwijzen om de claim van het slachtoffer geheel of gedeeltelijk af te wijzen. Zo blijven vele rechters in de Verenigde Staten in verband met de aansprakelijkheid voor skiongelukken de term 'implied assumption of risk' hanteren, terwijl zij in feite bedoelen dat het slachtoffer zijn schade niet kan afwentelen op een derde, omdat deze tegenover het slachtoffer geen 'duty of care' heeft en er enkel sprake is van risico's die inherent zijn verbonden aan de beoefening van de ski- of wintersport. ${ }^{30}$ Deze situatie wordt in de Amerikaanse rechtsleer doorgaans aangeduid met de, enigszins verwarrende, term 'primary assumption of risk'. ${ }^{31}$

Het valt toe te juichen dat de leer van de risicoaanvaarding, zowel in de landen van de 'common law' als in de continentale rechtsstelsels, stevig op zijn retour is. Zo gaat men er in verschillende staten van de VS tegenwoordig van uit dat 'assumption of risk', gelet op de kritiek die er in de literatuur tegen het gebruik van deze theorie is geuit, zich situeert binnen het onderzoek naar 'comparative negligence', dat wil zeggen het afwegen van de fout van de benadeelde en die van de aangesprokene, ${ }^{32}$ terwijl in Frankrijk het Hof van Cassatie de leer een gevoelige slag heeft toegebracht door te oordelen dat ook bij toepassing van de objectieve aansprakelijkheid voor zaken (art. 1240 lid 1 Code civil) op de theorie van de 'acceptation des risques' geen beroep meer kan worden gedaan. ${ }^{33}$

In het kader van de sneeuwsporten wordt op de eigen schuld van de benadeelde trouwens regelmatig een beroep gegaan. ${ }^{34}$ In dat verband verdient specifiek aandacht dat tussen de onderzochte stelsels erg belangrijke verschillen zijn aan te merken ter zake van de vraag hoe om te gaan met eigen schuld van minderjarigen. In de meeste rechtsstelsels wordt aangenomen dat kinderen geen eigen schuld kan worden aangerekend, hetzij op grond van hun jeugdige leeftijd (als spiegelbeeld van het feit dat zij op grond van hun leeftijd niet aansprakelijk kunnen worden gesteld voor schade die zij aan derden veroorzaken), hetzij omdat zij niet bekwaam zijn de gevolgen van hun risicovolle gedrag in te schatten. ${ }^{35}$ In andere stelsels is de minderjarigheid van het slachtoffer echter geen reden om eigen schuld uit te sluiten. Zo geldt naar Frans recht nog steeds de, zij het bekritiseerde, toepassing van de regel dat de schade van een

30. Zie daarover uitvoerig Feldman \& Stein 2010.

31. Zie daarover J.L. Diamond, L.C. Levine \& A. Bernstein, Understanding Torts, Durham: Carolina Academic Press 2013, p. 235 e.v.

32. Diamond, Levine \& Bernstein 2013, p. 240 e.v.

33. Cass. fr. 4 november 2010, D. 2010, 2772 m.nt. I. Gallmeister.

34. Zie bijv. het rechtspraakoverzicht met betrekking tot aansprakelijkheid inzake skiongelukken naar Oostenrijks recht: www.uibk.ac.at/ sportrecht/judikatur.html.

35. Zie hierover de grondige analyse van de aansprakelijkheid jegens minderjarigen in M. Martin-Casals (red.), Children in Tort Law. Part II: Children as Victims, Wenen: Springer 2007. minderjarig slachtoffer van een wintersportongeluk kan worden verminderd op grond van de door hem gemaakte, objectief te beoordelen, fout, zonder dat daarbij rekening mag worden gehouden met zijn subjectieve bekwaamheid. ${ }^{36}$ Sinds 1984 werd het subjectieve vereiste van toerekenbaarheid ('imputabilité) in Frankrijk immers afgeschaft, niet alleen met betrekking tot de aansprakelijkheid van de minderjarige dader, ${ }^{37}$ maar ook ten aanzien van de minderjarige als foutief handelend slachtoffer. ${ }^{38}$

\subsection{Stelling 4: over de intensiteit van de onrechtmatige gedraging}

'Ein regelkonformes Schädigerverhalten indiziert keinen Verkehrspflichtversto $\beta$. Vielmehr ist positiv festzustellen, dass ein Regelversto $\beta$ von signifikanter Intensität zur Schädigung des verletzten Sportlers geführt hat. ${ }^{39}$

Zeker met betrekking tot contactsporten wordt in tal van uitspraken over aansprakelijkheid beoordeeld of er sprake was van opzet of van grove schuld. Die benadering treffen we bijvoorbeeld aan in het Amerikaanse aansprakelijkheidsrecht. In tegenstelling tot situaties waarbij er van een 'duty of care' geen sprake is met betrekking tot risico's die 'part and parcel of the sport' zijn, moeten medespelers er wel voor zorgen dat de risico's niet onnodig worden verhoogd: 'The defendant owes a duty to use care to avoid increasing the sports's inherent risks. ${ }^{40}$ Hieruit wordt meestal afgeleid dat het gedrag minstens als roekeloos moet kunnen worden aangemerkt: 'The defendant's conduct must therefore rise to the level of recklessness, not negligence. ${ }^{41}$

Die lijn vinden we ook in de Nederlandse doctrine en jurisprudentie terug. Zo schrijft Cees van Dam terecht dat, wat contactsporten betreft,

'voor aansprakelijkheid een mate van hardheid is vereist die uitgaat boven hetgeen bij de desbetreffende sport op het feitelijk beoefende niveau als acceptabel geldt. Hiervan zal veelal sprake zijn als de scheidsrechter een speler om die reden van het veld heeft gestuurd of had moeten sturen. ${ }^{\text {‘2 }}$

36. Zie over deze problematiek uitvoerig P.C.J. De Tavernier, De buitencontractuele aansprakelijkheid voor schade veroorzaakt door minderjarigen, Antwerpen: Intersentia 2006, p. 100 e.v., nrs. 130 e.v.

37. Cass. fr. ass. plén. 9 mei 1984 (Fullenwarth), D. 1984, J., 525, concl. J. Cabannes en noot F. Chabas, J.C.P. 1984, II, nr. 20255 m.nt. N. Dejean de la Bâtie.

38. Cass. fr. ass. plén. 9 mei 1984 (Derguini \& Lemaire), D. 1984, p. 525 m.nt. F. Chabas.

39. Dördelmann 2018, p. 353-354.

40. Zie A. Pittman, J.O. Spengler \& S.J. Young, Case Studies in Sport Law, Champaign, IL: Human Kinetics 2016, p. 79. Zie daarover ook Diamond, Levine \& Bernstein 2013, p. 241.

41. Zie J.J. Miller \& K.L. Schoepfer, Legal Aspects of Sports, Burlington: Jones \& Barlett Learning 2018, p. 20.

42. Van Dam 2000, p. 432, nr. 1518 


\section{Maandblad}

Echter, zoals onder stelling 6 zal worden vermeld, is een rode kaart voor enkel spelbederf niet voldoende. Men denke aan de situatie waarbij een speler een tegenstrever neerlegt om hem daarmee van een doelrijpe kans te ontroven. Ook het enkele feit dat een strafschop is toegekend, is niet voldoende voor het aannemen van aansprakelijkheid. ${ }^{43}$

Het moet dus, zoals Van Bunge aangeeft in haar masterscriptieonderzoek, gaan om een abnormaal gevaarlijke gedraging en niet om een gevaar dat 'eigen is aan een sport als voetballen en dat de deelnemers aan de sport over en weer van elkaar te verwachten hebben, maar om een gevaar dat zich bij de voetbalsport, als zij normaal wordt beoefend, niet zal voordoen'. ${ }^{44} \mathrm{Als}$ voorbeeld noemt Van Bunge een karatetrap in het gelaat, een vliegende tackle of een inkomen met gestrekt been dan wel beide benen. ${ }^{45}$

Met betrekking tot contactsporten gaat het echter te ver om te oordelen dat opzet of grove schuld een vereiste is voor aansprakelijkheid in sport- en spelsituaties. Het is wel een belangrijke factor, maar geen doorslaggevende factor, die van invloed is op het oordeel of er in een gegeven situatie tot onrechtmatigheid kan worden besloten. ${ }^{46}$

\subsection{Stelling 5: over het onderscheid tussen contactsporten en niet-contactsporten}

'Eine pauschale Differenzierung zwischen einzelnen Sportarten - etwa zwischen Kampf- und Parallelsport oder Sportarten mit erheblichem und unerheblichem Gefährdungspotential - ist abzulehnen, da aus einer solchen Aufteilung eine ungerechtfertigte Benachteiligung bestimmter Sportarten im haftungsrechtlichen Sinne resultiert. ${ }^{47}$

In het licht van de dubbele grondslag van wederkerigheid van risico op schade ('Reziprozität') en de eigen kenmerken van de beoefende sport ('Typizität') is de stelling van Dördelmann om 'eine pauschale Differenzierung' tussen niet-contactsporten en contactsporten af te wijzen verrassend te noemen. Spreekt de auteur zich daarmee niet tegen? Immers, bij contactsporten is het risico op letsel aanzienlijk, maar vormt de aard van de gedraging een belemmering voor het nemen van omvangrijke voorzorgsmaatregelen. ${ }^{48} \mathrm{Bij}$ niet-contactsporten staat de aard van de gedraging niet in de weg aan het nemen van uitgebreide voorzorgsmaatregelen, als deze geen belemmering vormen voor het adequaat beoefenen van de desbetreffende sport. ${ }^{49}$

43. Van Dam 2000, p. 432, nr. 1518.

44. HR 28 juni 1991, ECLI:NL:HR:1991:ZC0300 (Natrappen), r.o. 3.2.

45. Van Bunge 2019, p. 20, met verwijzingen naar rechtspraak aldaar.

46. C.R.R.M. Niessen, Sportaansprakelijkheid: beslist geen spelletje, TvS\&R 2018, p. 34.

47. Dördelmann 2018, p. 351.

48. Van Dam 2000, p. 427.

49. Van Dam 2000, p. 433. Zie over het belang van het onderscheid ook C. von Bar, Gemeineuropäisches Deliktsrecht, München: C.H. Beck'sche Verlagsbuchhandlung 1999, p. 285.
Laten wij de voetbalsport, een contactsport bij uitstek, en de skisport, een niet-contactsport, er even bij nemen. Bij voetbal zijn bepaalde risico's niet te vermijden. Zonder het nemen van dergelijke fysieke risico's kan men de sport niet volledig, of eigenlijk geheel niet, beoefenen. Bij niet-contactsporten, zoals skiën, zijn er daarentegen voorzorgsmaatregelen mogelijk en is het beperken van de risico's (in theorie) minder problematisch voor het beoefenen van de sport. ${ }^{50}$ Zoals al eerder besproken, leidt de miskenning van een FIS-regel in beginsel eerder tot aansprakelijkheid dan een schending van een spelregel van de KNVB. Dit onder meer omdat men in een contactsport als voetbal wel contact kan verwachten en dit juist relevant is bij de beoordeling wat onzorgvuldig is binnen de sport- en spelsituatie. Overtredingen behoren immers tot het moderne voetbal en een overtreding door een gebrekkige techniek, door een verkeerde taxatie van de situatie of door onrechtmatige inzet is praktisch onvermijdelijk.

In de skisport is enig contact echter al bijzonder gevaarlijk, mede gezien de uitrusting, de snelheid en de kracht waarmee men de piste af komt glijden. Een overtreding van de FISregels leidt, mits bewezen, in de praktijk vrijwel altijd tot onrechtmatigheid. ${ }^{51}$ Hetzelfde kan niet worden gezegd van een overtreding van de voetbalspelregels. Zo sluit bijvoorbeeld Wijnkamp daarom terecht aan bij de stelling dat de eigen aard van de skisport belangrijk is bij de vraag of bij de skisport wel gebruik mag worden gemaakt van de verhoogde aansprakelijkheidsdrempel (en dat het typische karakter van de skisport dus wel degelijk relevant is bij de beoordeling van de aansprakelijkheid van de skiër ten aanzien van andere deelnemers aan het skisportgebeuren). ${ }^{52}$

\subsection{Stelling 6: over de impact van de scheidsrechterlijke beslissing}

'Der Richter ist im Rahmen seiner Entscheidungsfindung nicht an die sportinternen Entscheidungen eines Sportschiedsrichters gebunden (...). Die Aussage eines Sportschiedsrichters kann im Zivilprozess eine wesentliche Bedeutung bei der Sachverhaltungsaufklärung erlangen; sie kann allerdings auch vollkommen unbrauchbar sein. ${ }^{53}$

50. Ook bij het beoefenen van de skisport zullen er deelnemers zijn die (onopzettelijk) niet de oplettendheid betrachten die vereist is en daardoor (onopzettelijk) gevaarlijke situaties in het leven roepen. Als daardoor ongelukken gebeuren, is er echter geen reden om dan met (zwaar) verhoogde aansprakelijkheidsdrempels te werken. In wezen geldt hetzelfde in het verkeer. Daarbij weet men ook dat er best een grote kans bestaat dat andere verkeersdeelnemers fouten maken. Maar dat is geen reden om in het verkeer met verhoogde aansprakelijkheidsdrempels te werken. Integendeel: het verkeer vereist juist extra oplettendheid, omdat iedereen weet dat het risico op ongelukken groot is als men onvoldoende oplet.

51. Van Bunge 2019, p. 21-22.

52. S. Wijnkamp, Een ski-ongeval in Oostenrijk. Wat nu?, L\&S 2013, afl. 4, p. 35, met verwijzing naar HR 11 november 1994, ECLI:NL:HR 1994:ZC1533, NJ 1996/376 m.nt. C.J.H. Brunner (Judoworp).

53. Dördelmann 2018, p. 354. 


\section{Maandblad \\ Vermogensrecht}

Deze stelling betreft de vraag in welke mate de rechter bij de beoordeling van de aansprakelijkheid van een medespeler gewicht moet toekennen aan de beslissing van de scheidsrechter. Deze problematiek hangt nauw samen met het beginsel dat de miskenning van een spelregel op zich geen voldoende reden is om een speler aansprakelijk te stellen. Zo wordt naar Belgisch recht, zowel in de lagere rechtspraak als in de arresten van het Hof van Cassatie, geoordeeld dat de bestraffing van een gele kaart weliswaar dient als gegeven dat in overweging kan worden genomen, maar niet determinerend is bij de bepaling van de foutaansprakelijkheid. ${ }^{54}$ Een scheidsrechterlijke uitspraak, zoals het tonen van de gele kaart, kan dus weliswaar een invloed hebben op de foutbeoordeling door de burgerlijke rechter, maar toch is deze rechter er niet door gebonden, omdat beslissingen van scheidsrechters geen kracht van wet hebben. ${ }^{55}$ Dat is naar Nederlands recht niet anders. De beslissing van de scheidsrechter is zeker niet bepalend. Dat neemt niet weg dat ook naar Nederlands recht met betrekking tot de uitleg van de spelregels en de vraag of in de gegeven omstandigheden de spelregels zijn overtreden (zie hiervoor stelling 2) gewicht toe kan komen aan het oordeel van een scheidsrechter. Ter illustratie verwijs ik naar een vonnis van de kantonrechter Zwolle, waarin veel belang wordt gehecht aan het feit dat de scheidsrechter een 'sliding tackle' met een gele kaart had bestraft en niet met een rode kaart. ${ }^{56}$ Maar er zijn ook gevallen aan te wijzen waarin bij het oordeel over de aansprakelijkheid geen enkele zin wordt gewijd aan het oordeel van de scheidsrechter. ${ }^{57}$

De komst van de videoscheidsrechter ('VAR') binnen het voetbal biedt de rechter ongetwijfeld ruimte om meer gewicht toe te kennen aan het oordeel van de scheidsrechter (en de videoscheidsrechter) bij het onrechtmatigheidsoordeel. De scheidsrechters kunnen immers de gedraging van een medespeler uit alle hoeken en standen terugzien en zo een weloverwogen oordeel vellen over de vraag of diens gedraging in strijd is met de spelregels. Een dergelijke beslissing komt meer gewicht toe dan een oordeel van een scheidsrechter die binnen enkele seconden moet oordelen. ${ }^{58}$

\subsection{Stelling 7: over de relevantie van de leeftijd en de beroepsbekwaamheid van de deelnemer}

'Einzelne typische Problemfelder der Verkehrspflichtkonkretisierung können oftmals einer persönlichen, zeitlichen, sachlichen oder örtlichen Dimension zugeordnet werden (...). Eine Differenzierung des Sorgfaltniveaus auf Grund-

54. P.C.J. De Tavernier, Rechter tackelt arbiter: wel geel maar geen fout, De Juristenkrant 2002, p. 7. Zie ook Cornelis \& Claeys 2003, p. 584 en de verwijzingen aldaar.

55. De Tavernier 2002, p. 7; Cornelis \& Claeys 2003, p. 584 en de verwijzingen aldaar.

56. Rb. Zwolle (ktr.) 10 augustus 1999, ECLI:NL:KTGZWO:1999:AJ0061, Prg. 2000/5471, r.o. 4.2. Zie daarover Niessen 2018, p. 34-35. Zie ook Van Bunge 2019, p. 11.

57. Van Bunge 2019, p. 11

58. Van Bunge 2019, p. 12 lage von Alters- und Leistungsklassen kann vorgenommen werden.'

In het raam van sport- en spelbeoefening rijst de interessante vraag wat de weerslag is van de leeftijd en de beroepsbekwaamheid van de sport- of speldeelnemer. Over het algemeen wordt aangenomen dat bij de invulling van de zorgvuldigheidsnorm wel rekening wordt gehouden met externe, maar niet met interne kenmerken. Interne kenmerken zijn deze die in de persoon van de schadeveroorzaker zijn gesitueerd, zoals leeftijd, geslacht, intelligentie en karakter. ${ }^{59}$

Over de vraag of met de leeftijd van een sport- of speldeelnemer rekening mag worden gehouden bij de toetsing van de zorgvuldigheid bestaat geen eensgezindheid. ${ }^{60}$ Sommigen menen van wel. Zo wordt naar Belgisch recht onder meer aangevoerd dat er geen rekening mag worden gehouden met intellectuele of psychologische factoren, omdat die de rechter er noodzakelijkerwijze toe zouden leiden om zich in te laten met het forum internum van het individu. Deze toetsing belet evenwel niet dat interne omstandigheden, voor zover deze objectiveerbaar zijn, wel mee kunnen worden gewogen bij de zorgvuldigheidstoetsing. ${ }^{61}$ Ook de leeftijd is een objectiveerbaar kenmerk, zo oordeelt men. Ik sluit mij niet aan bij deze opvatting. In de eerste plaats lijkt het mij overbodig dat de rechter rekening houdt met de leeftijd van de schadeveroorzaker. In vrijwel alle rechtsstelsels bevat het foutbegrip immers ook een subjectief element. De onrechtmatige daad moet immers aan de schadeverwekker toerekenbaar zijn. De schadeverwekker moet bewust en vrij hebben gehandeld. Er moet dus worden onderzocht of er op grond van zijn persoonlijke kenmerken (leeftijd, geslacht, intelligentie, karakter) geen verwijt kan worden gemaakt over het gestelde gedrag. In de tweede plaats mist een gesubjectiveerd onrechtmatigheidsvereiste het karakter van een norm die duidelijk maakt welk gedrag niet geoorloofd is. In de derde plaats brengt de subjectivering mee dat de vestiging van kwalitatieve aansprakelijkheden, bijvoorbeeld die van de ouders van een minderjarige sport- of speldeelnemer, wordt verhinderd, omdat die de aanwezigheid van een fout, of minstens een objectief onrechtmatige daad, vereisen. ${ }^{62}$

En wat te doen met de beroepsbekwaamheid van de sport- of speldeelnemer? Mag de rechter bij de zorgvuldigheidstoets rekening houden met het gegeven dat de veroorzaker van de schade een professional dan wel een amateur is? ${ }^{63}$ In de literatuur wordt over het algemeen aangenomen dat de beroepsbekwaamheid ervoor zorgt dat de zorgvuldigheidsnorm anders

59. Zie hierover bijv. T. Vansweevelt \& B. Weyts, Handboek buitencontractueel aansprakelijkheidsrecht, Antwerpen: Intersentia 2009, p. 128-129.

60. Over het laten meewegen van de leeftijd van de schadeveroorzaker in het onrechtmatigheidsoordeel, zie De Tavernier 2006, p. 138 e.v.

61. B. Dubuisson, Autonomie et irresponsabilité du mineur, in: Documents du Centre de droit des obligations, Louvain-la-Neuve 1997, p. 10, nr. 11.

62. De Tavernier 2006, p. 140, nr. 191 en de verwijzingen aldaar.

63. Zie hierover uitvoerig Q. De Raedt, Het foutbegrip bij sportbeoefenaars: amateurs vs. professionelen, TBBR 2012, p. 177-182. 
wordt ingevuld bij professionals. Er is geen reden om dit niet te aanvaarden in het raam van de sport- of spelbeoefening. ${ }^{64}$ Zo oordeelde, naar Belgisch recht, de rechtbank van eerste aanleg te Gent dat van een geoefende speler kan worden verwacht dat hij zijn kracht kan bedwingen in functie van de concrete spelomstandigheden. ${ }^{65}$ Kan daarom worden gesproken van een verhoogde of een verlaagde zorgvuldigheidsnorm? Dit is lastig, aangezien de norm weliswaar wordt aangepast, maar het in abstracto niet mogelijk is om vast te stellen welke norm de strengste is. Zo besliste het hof van beroep te Gent dat de naleving van de zorgvuldigheidsnorm des te meer geldt voor een profvoetballer die de limieten van zijn eigen mogelijkheden en van de toegepaste technieken beter kent of dient te kennen dan een amateurvoetballer. ${ }^{66}$ Datzelfde hof van beroep oordeelde in 2002 echter ook dat amateurs des te voorzichtiger dienen te zijn wanneer zij manoeuvres uitvoeren die zij nog niet helemaal onder de knie hebben, aangezien een wedstrijd niet bedoeld is om technieken te trainen. ${ }^{67}$ Er blijkt dus dat in beide gevallen aan een andere zorgvuldigheidsnorm is getoetst, maar dat hierbij moeilijk kan worden gesteld dat de ene strenger is dan de andere. ${ }^{68}$ Betekent het voorgaande dat bij de invulling van de zorgvuldigheidsnorm voor amateurs geen rekening wordt gehouden met het eventuele gebrek aan bepaalde vaardigheden? Uit de rechtspraak blijkt dat dit wel het geval is. Hoewel er, omwille van hun hoedanigheid van amateur, geen sprake is van een afwijkend zorgvuldigheidscriterium voor amateurs in het algemeen, deinst de rechtspraak er niet voor terug rekening te houden met het gebrek aan kennis en ervaring van de persoon, door rekening te houden met diens persoonlijke, interne kenmerken. ${ }^{69}$

\section{Besluit}

$\mathrm{Na}$ de voorgaande tour d'horizon langs zeven stellingen uit het proefschrift van Dördelmann sluit ik deze recensie af met enkele korte overwegingen.

Graag druk ik, zoals in de inleiding, nogmaals mijn lof uit voor de grondige en strak gestructureerde wijze waarop de auteur zijn onderzoek heeft verricht. Als proefschrift vind ik het boek dan ook zeer geslaagd. Of het boek door de rechtspraktijk zal worden omarmd, valt evenwel te betwijfelen. Daarvoor vind ik de studie te juridisch-dogmatisch. De auteur had er goed aan gedaan om het door hem voorgestelde referentiekader en, daaraan gekoppeld, de criteria die de rechter ten dienste staan bij de beoordeling van de aansprakelijkheid van deelnemers bij sport en spel onderling wat meer te toetsen aan de jurisprudentie. Dat had het boek zeker wat meer lucht gegeven en daarom ook toegankelijker gemaakt.

\footnotetext{
64. De Raedt 2012, p. 181, nrs. 12-13.

65. Rechtbank van eerste aanleg Gent 18 februari 2000, TGR 2000, 105.

66. Hof van Beroep Gent 6 februari 1992, RW 1992-93, 570 m.nt. M. Adams \& M. Van Hoecke.

67. Hof van Beroep Gent 22 november 2002, NjW 2003, 93 m.nt. I. Boone.

68. De Raedt 2012, p. 181, nr. 13.

69. De Raedt 2012, p. 182, nr. 14.
}

Het boek prikkelt met duidelijke stellingnames en de onderbouwing daarvan. Toch is het boek, mede gelet op de door mij gemaakte vergelijking van enkele centrale stellingen van de auteur met het geldende recht in bijvoorbeeld Nederland en België, op vele punten niet vernieuwend te noemen. De visie van de auteur sluit immers vrij nauw aan bij de antwoorden die in het vigerende Europese aansprakelijkheidsrecht zijn verwoord. Deze gedachte moet niet geheel als kritiek worden opgevat. Misschien toont de eensgezindheid over tal van issues met betrekking tot de aansprakelijkheid van deelnemers bij sport en spel aan dat het huidige, flexibele juridische referentiekader gewoonweg goed functioneert.

Het uitgebreide notenapparaat en de indrukwekkende bibliografie van het boek vormen een rijke schat aan informatie voor hen die zich in de problematiek van de aansprakelijkheid bij sport en spel verder willen verdiepen. Daarom verdient het aanbeveling dat het boek op termijn wordt verwerkt tot een voor de praktijk toegankelijk(er) compendium. Het zou jammer zijn als de waardevolle inzichten van Dördelmann niet de gewenste verspreiding krijgen die ze verdienen. 